\title{
Membrane distillation of concentrated blackwater: Effect of temperature, solids concentration and membrane pore size
}

\author{
F. Kamranvand ${ }^{1}$, C. J. Davey ${ }^{1}$, L. Williams ${ }^{2}$, A. Parker ${ }^{1}$, Y. Jiang ${ }^{3}$, S. Tyrrel' ${ }^{1}$, \\ E. J. McAdam ${ }^{*}$ \\ ${ }^{1}$ Cranfield Water Science Institute, Cranfield University, Bedfordshire, MK43 OAL, UK; ${ }^{2}$ Centre for Creative \\ and Competitive Design, Cranfield University, Bedfordshire, MK43 OAL, UK; ${ }^{3}$ Centre for Thermal Energy \\ Systems and Materials, Cranfield University, Bedfordshire, MK43 OAL, UK \\ ${ }^{*}$ Corresponding author: e.mcadam@cranfield.ac.uk
}

\begin{abstract}
This study has elucidated the mechanisms governing water recovery from blackwater using membrane distillation, and has clarified the role of the organic particle fraction on membrane performance. Whilst faecal pathogen growth was initially observed at lower temperatures, pathogen inactivation was demonstrated over time, due to urea hydrolysis which liberated ammonia in excess of its toxic threshold. During the growth phase, membrane pore size $<0.45 \mu \mathrm{m}$ was sufficient to achieve high log reduction values for $E$. Coli, due to size exclusion complimented by the liquid-vapour interface which enhances selective transport for water. Higher feed temperatures benefitted rejection by promoting thermal inactivation and suppressing urea hydrolysis. Whilst the mechanism is not yet clear, suppression of hydrolysis reduced bicarbonate formation kinetics stabilising the ammonia-ammonium equilibrium which improved ammonium rejection. Blackwater particle concentration was studied by increasing faecal content. Particle fouling improved selectivity for coarse pore membranes but increased mass transfer resistance which reduced flux. Particle fouling induced wetting as noted by an eventual breakthrough of feed into the permeate. We propose that by incorporating upstream solid-liquid separation for particle separation to limit wetting and mass transfer resistance, membrane distillation can be a reliable solution for the recovery of high quality permeate from blackwater.
\end{abstract}

Keywords: sanitation, organic fouling, pathogen rejection, particle and colloid, vacuum, water quality

\section{Introduction}

Decentralised sanitation can deliver treatment at a favourable cost through avoiding investment in distributed networks (Holler, 2003). Pit latrines are presently one of the 
most commonly applied decentralised sanitation solutions that are often implemented at household scale (Hutton, 2013). Typically pit latrines receive only blackwater (wastewater from toilets) and operate without the inclusion of flush water. This absence of up to 26 litres of additional water per flush means dry toilets produce a more concentrated blackwater compared to traditional flush toilets (Kasenow, 1997). Whilst pit latrines have achieved significant market penetration, they are a temporary storage solution, prone to flooding and leaching into local groundwater resources (Tillett, 2013, Tilley 2014). Unregulated discharge of untreated faecal sludge into the environment upon pit emptying is also common place and recognised to negatively impact on human health (Strauss, 2002).

An alternative proposition is to introduce treatment solutions for concentrated blackwater at this scale. Such intervention can offer safe discharge to the local environment, in addition to reducing the required storage volume within pit latrines. Pitlatrine emptying costs are around 0.50 to $6.00{\text { US } \$ \text { capita }^{-1} \text { annum }}^{-1}$ (WASHCost, 2012) which represents a significant proportion of income for the 3.1 billion people in low income countries that survive on 2 to 4 US $\$$ capita $^{-1} \mathrm{~d}^{-1}$ (Chen \& Ravallion, 2010). Cost avoidance may therefore provide one of several financial benefits to stimulate market adoption of treatment technologies by end-users. For 'low' or no flush applications, the liquid phase discharge is therefore primarily urine which is low in volume (c. $1.5 \mathrm{~L}^{-}$capita ${ }^{1} \mathrm{~d}^{-1}$ ) (Rose et al., 2015) but is highly concentrated and likely to be contaminated with faeces. The extent of contamination is strongly dependent on the phase separation provided by the toilet design (e.g. source separation) (Mercer et al., 2016). Therefore delivering the necessary treatment is a complex challenge, not least due to the organic concentration, and the significant reduction in pathogen count demanded if safe discharge is to be achieved at a single household scale (Mercer et al., 2016).

Electrochemical oxidation has been proposed, which provides for the reduction of organics and disinfection of pathogens for an electrical energy demand of around $180 \mathrm{Wh}$ capita-1 $^{-1} \mathrm{~d}^{-1}$ (Cid et al., 2018). An alternative approach is to apply reverse osmosis that can provide highly selective water separation versus inorganics, organics and pathogens, sufficient to deliver water of comparable standards (Lee \& Lueptow, 2001; Madaeni, 1999). However, the poor rejection of small organics such as urea will limit permeate quality (Bellona et al., 2004), whilst the osmotic pressure provided by the salts within urine will contribute toward energy requirement, limiting recovery ratios (Maurer et al., 2006) and therefore making down scaling of pump technology difficult. In addition, since strong oxidants cannot be applied to the membrane, sustaining membrane 
permeability in the long-term demands extremely high quality feed pre-treatment. In both cases, the technologies are dependent on a considerable electrical power demand, which is high risk in low-income countries where networked power supplies are extremely fragile (IEA, 2011; Bazilian et al., 2012). Alternatively, membrane distillation (MD) uses thermal energy to develop a vapour pressure gradient across a hydrophobic microporous membrane to deliver the selective separation of water vapour, whilst the small pore structure can further enhance the selectivity that can be achieved (Kamranvand et al., 2018). Due to the high specific surface area that can be facilitated, water vapour transport can be achieved using lower quality heat accessible in low income countries through technologies such as solar thermal (Banat et al., 2007) or biogas (Khan \& Martin, 2015). Furthermore, distillation technology is scaled on volume and not concentration, making it suitable for the treatment of low volume concentrates to high recovery ratios.

Zhao et al. (2013) demonstrated successful water recovery rates from urine using $M D$, as well as the production of extremely high-quality water, including $>99 \%$ removal of organic and inorganic constituents. However, concentrated blackwater is considerably more complex, comprising a higher organic concentration, including a considerable particle fraction, as well as a pathogenic concentration exceeding $10^{6} \mathrm{~mL}^{-1}$ (Dufour, 1977). In a provisional feasibility study by Kamranvand et al. (2018) analogous separation performance to Zhao et al. (2013) was noted for urine, however, the inclusion of faecal contamination induced breakthrough, presumably through the wetting of the coarse pores of the expanded polytetrafluoroethylene (PTFE) hollow fibre membrane (average pore width and length, 0.2 and $5 \mu \mathrm{m}$ respectively) employed. The authors proposed that the introduction of narrower pores, together with the inclusion of upstream intervention to constrain surface fouling could enhance separation and sustain membrane permeability. However, the sensitivity of the membrane to such feed conditions, together with the explicit mechanisms that determine selectivity of hydrophobic membranes for separation of the broad suite of contaminants, particularly the rejection capacity for pathogens, has not been well described (Christiaens et al., 2019). Blackwater also comprises of volatile organic and inorganic constituents that may demand specific operational conditions to improve the apparent selectivity. The aim of this study is therefore to establish the role of membrane pore size on enhancing both selectivity and resilience to wetting by this organic rich feed matrix, whilst also establishing the feed conditions and boundary conditions needed to drive permeate quality through enhancing selectivity. This will inform the decision on possible 
requirements for upstream interventions to enable the utilisation of this technology within decentralised sanitation.

\section{Materials and Methods}

\subsection{Experimental set-up}

The same vacuum membrane distillation (VMD) set-up was used for all experiments (Figure 1). A Perspex membrane cell included a flatsheet membrane on a supportive mesh, sited in a recess $(2 \mathrm{~cm} \times 10 \mathrm{~cm}$, and height of $0.5 \mathrm{~cm})$ in which the permeate channel was sloped at $2^{\circ}$ to minimise the risk of condensate development. An initial feed volume of $250 \mathrm{~mL}$ of real concentrated blackwater consisting of only urine and faeces was used. This was circulated through a rectangular channel above the membrane $(0.4$ $\mathrm{cm}$ in depth) using a peristaltic pump (Masterflex L/S, Cole-Parmer, London, UK) at a flow rate of $500 \mathrm{~mL} \mathrm{~min}^{-1}$ to sustain a crossflow velocity of $0.1 \mathrm{~m} \mathrm{~s}^{-1}$ over the membrane surface (Figure 1). Unsupported hydrophobic polytetrafluoroethylene (PTFE) flat sheet membranes (Cobetter filtration, Hangzhou, China) with nominal pore sizes of $0.1,0.45$, 1 , 3, or $5 \mu \mathrm{m}\left(0.0056 \mathrm{~m}^{2}\right)$, were placed on a stainless-steel mesh support (Appendix $A$ ). The mesh had a total of 201 holes through which it exposed the total active membrane surface area of $791.4 \mathrm{~mm}^{2}$. The feed was continuously mixed at $150 \mathrm{rpm}$ using an overhead stirring system (Tornado ${ }^{\mathrm{TM}}$, Radley Ltd, Saffron Walden, UK) and heated to 40,50 , or $60^{\circ} \mathrm{C}$ on a dry heater (Breeze ${ }^{\mathrm{TM}}$, Radley Ltd, Saffron Walden, UK) integrated with a recirculating heater / chiller (Ministat 230 Pilot ONE Controller, Huber Technology, Chippenham, UK). Vacuum was introduced to the permeate side of the membrane at $140 \pm 9$ mbar (ME 1, Vacuubrand, Brackley, UK). Vacuum pressure (PXM319-001A10V, Omega Ltd., Manchester, UK) and feedwater pressure (PXM319-001G10V, Omega Ltd., Manchester, UK) were measured using pressure transducers. Feed temperature was measured using k-type thermocouples (El1034, LabJack Corporation, Lakewood, USA). Permeate was collected using a cold temperature condenser $\left(2{ }^{\circ} \mathrm{C}\right)$ (GPE Scientific, Leighton Buzzard, UK) and a condensation trap (Scientific Glass Laboratories Limited, Stoke-On-Trent, UK). A temperature of $2{ }^{\circ} \mathrm{C}$ was sustained in the condenser using a recirculating chiller (LT ecocool chiller, Grant Instruments, Cambridge, UK). During the experiment, the permeate mass was measured temporally on an analytical balance (Symmetry PT - 413I PT-Series Precision Toploading Balance, Cole-Parmer, London, UK). 


\subsection{Feedwater preparation}

Human faeces and urine were collected anonymously in accordance with methods approved through the Cranfield University Ethics Review system (CURES: 2310/2017; 2407/2017). Samples were collected directly in either disposable cardboard bowls (faeces) or polypropylene pots (urine). The concentrated blackwater was prepared by mixing collected urine with faeces to fixed faecal contaminations of $0.0,0.4,1.8$ and 6.7 wt.\%. This covers a representative range of urine to faeces produced by individuals on a daily basis (Rose et al., 2015) with the upper threshold representing a daily production of $\sim 2 \mathrm{~L}$ urine and $\sim 145 \mathrm{~g}$ faeces per day, whilst also assuming no flush water inclusion. Blackwater was made by stirring the mixture at $400 \mathrm{rpm}$ for 20 minutes, using an overhead stirrer (Hei-TORQUE Precision 400, Heidolph Instruments GmbH \& CO. KG, Nuremberg, Germany), to create the most concentrated sample that can be fed to the process to examine the membrane process removal efficiency under extreme conditions. Following homogenisation, the feedwater was sieved using a $2 \mathrm{~mm}$ stainless-steel mesh (Fisher Scientific, Loughborough, UK) to prevent tube clogging by large particles, nevertheless the COD at 6.7 wt \% was around $20,000 \mathrm{mg} \mathrm{L}^{-1}$ or twenty times more concentrated than traditional blackwater (van Voorthuizen et al., 2008). In practice, basic upstream solid-liquid separation will reduce solids content and thus faecal contamination of the blackwater, but the upper threshold was sustained in this study to identify process resilience in a characteristic concentrated blackwater.

\subsection{Analytical methods}

Concentration of ammoniacal nitrogen and Chemical Oxygen Demand (COD) was determined through spectrophotometric methods (Spectroquant ${ }^{\circledR}$ cell tests, Merck Millipore, Watford, UK). To minimise losses of ammonia in storage, analysis was conducted directly at the time of sampling. Solution $\mathrm{pH}$ was measured using a $\mathrm{pH}$ meter (Testo 0563 2061, RS Components Ltd., Corby, UK). The 9215C and 9215D methods together with 9922B and 9922D from Standard Methods for the Examination of Water and Wastewater (20 ${ }^{\text {th }}$ Edition, APHA) were applied for the analysis of viable Escherichia coli ( $E$. coli). Two methods were used for the enumeration of $E$. coli and determination of number of colony forming units (CFU): spread-plate using $0.1 \mathrm{~mL}$ feed sample, and membrane filtration using $10 \mathrm{~mL}$ permeate sample. The calculation of the log removal of E. coli was conducted using:

$$
\text { E. coli } \log \text { Removal }(\mathrm{LRV})=\log _{10}\left(\frac{C_{f}}{C_{p}}\right)
$$


where $C_{f}$ and $C_{p}$ are the number of CFU detected in the feed and permeate respectively.

Surface tension was measured using a ring tensiometer (K6 Force Tensiometer, Kruss, GmbH, Bristol, UK). Liquid contact angle of the PTFE membranes were measured using a goniometer (OCA 25 Contact Angle System, DataPhysics Instruments GmbH, Stuttgart, Germany). Membrane liquid entry pressure (LEP) for water was measured according to the method of Rácz et al. (2014). Due to the presence of suspended solids forming a fouling layer accurate LEP measurements for concentrated blackwater could not be performed and were therefore estimated by the Young-Laplace equation (Young, 1805; Franken et al., 1987; M. Rezaei et al., 2018):

$$
L E P=\frac{-B \gamma_{l} \cos \theta}{r_{\max }}
$$

where, $B$ is a pore geometry coefficient, $\gamma_{l}$ is the liquid surface tension, $\theta$ is the contact angle and $r_{\max }$ is the maximum pore size of the membrane. Electrical conductivity (EC) was measured in the feed and permeate during the experiment using a conductivity meter (Mettler Toledo, Leicester, UK).

\section{Results and Discussion}

\subsection{The effect of membrane pore size on membrane distillation of blackwater}

There is a critical relationship between the membrane properties and liquid characteristics in sustaining the liquid-vapour interface for a successful separation by membrane distillation. As membranes used in the majority of studies are not designed for specific membrane distillation applications, if the critical material properties are known, they can be defined and further optimised to offset wetting (Eykens et al., 2016). Consequently, a series of PTFE membranes with increasing average pore sizes were applied to establish their criticality on selective water recovery from concentrated blackwater. A concentrated blackwater comprising human urine and a high faecal solids fraction $(1.8 \% \mathrm{w} / \mathrm{w})$ was homogenised to present a 'worst case' scenario where no upfront solid-liquid separation is employed, to establish selectivity under perturbation that will inform more robust design. For a feed temperature of $60^{\circ} \mathrm{C}$, a larger average membrane pore size resulted in a much greater initial water flux at the outset of permeation (Figure 2a), with initial fluxes of 73.8 and $153.5 \mathrm{~kg} \mathrm{~m}^{-2} \mathrm{~h}^{-1}$ recorded for the 1 and $5 \mu \mathrm{m}$ membranes respectively. Molecular diffusion dominates over Knudsen diffusion for membrane pore sizes larger than $\sim 0.2 \mu \mathrm{m}$ (Winter et al., 2013; Eykens et al., 2016) and therefore a minimal difference in water flux between 1 and $5 \mu \mathrm{m}$ pore size membranes would be expected if the liquid-vapour interface was sustained. Following this initial 
period, pseudo steady state fluxes ranging between 16.5 and $18 \mathrm{~kg} \mathrm{~m}^{-2} \mathrm{~h}^{-1}$ were achieved for each pore size membrane.

Higher initial fluxes recorded for the coarse pore sizes were complemented by a low COD rejection of $24 \%$ to $63 \%$ (Figure $2 \mathrm{~b}$ ). This contradicts the performance of the $0.1 \mu \mathrm{m}$ pore size membrane which produced permeate of $0.043 \mathrm{gCOD} \mathrm{L}^{-1}$ which is below the US EPA standard for discharge $\left(0.15 \mathrm{gCOD} \mathrm{L}^{-1}\right)$. This distinction can be explained by the difference in liquid entry pressure (LEP) between pore sizes, since membrane pore size has an inverse relationship with LEP (Alkhudhiri et al., 2012) (Figure 3). Clean water analysis demonstrated that the liquid entry pressure for pore sizes greater than $1 \mu \mathrm{m}$ were comparable to or below the LEP, which would indicate immediate breakthrough under test conditions. Further reduction in LEP was recorded for real solutions, which can be ascribed to the lower surface tension of blackwater; this is a critical component in sustaining the vapour liquid equilibrium (Kamranvand et al., 2018). Therefore, since the vacuum pressure exceeds the LEP for coarse pore sizes, the high fluxes experienced at the outset, are due to direct pressure driven filtration, until a foulant layer is established which provides sufficient filtration resistance to retard mass transfer.

Following this initial period of filtration, a shift in mechanism was evidenced by a progressive increase in COD removal efficiency, coupled with establishing a steady-state permeate flux comparable to the $0.1 \mu \mathrm{m}$ membrane which exhibited an LEP $>3$ bar. To illustrate, for the 1 and $5 \mu \mathrm{m}$ membranes, permeate COD was initially around $5.1 \mathrm{gCOD} \mathrm{L}^{-1}$ and following the transition to this second period of filtration, produced effluent comparable to the US EPA discharge standard. To confirm that the selectivity fostered in the second phase of filtration was controlled by having re-established the vapour-liquid equilibrium after membrane fouling, permeate conductivity from blackwater was compared to that produced when different pore size membranes were subject to a synthetic solution (11.55 $\mathrm{gNaCl}$ in $\mathrm{DI}$ water) with comparable conductivity of urine; the conductivity being primarily a function of the presence of low molecular weight inorganic and organic salts (Putnam, 1971) (Figure 4). For synthetic solutions applied to clean membranes operated at $60^{\circ} \mathrm{C}$, rejection for conductivity declined sharply for pore sizes $>1 \mu \mathrm{m}$. In contrast, rejection for conductivity of the same pore size range was consistently $>80 \%$ during distillation of blackwater. We therefore propose that once the resistance of the foulant layer was sufficient to discontinue pressure filtration, distillation proceeded which would indicate that particle deposition does not obviously hinder the vapour-liquid equilibrium. Goh et al. (2013) demonstrated that whilst organic fouling introduces insulative properties, it has a minimal effect on heat resistance. In this study, 
the impact of insulative properties of the cake layer on conductive heat transfer will be negligible due to the permeate side vacuum (Alkhudhiri et al., 2012). However, particle deposition has been shown to influence mass transfer (Goh et al., 2013). This was confirmed in this study by comparing permeate flux data to solutions without particles in which fluxes of $27.5 \mathrm{~kg} \mathrm{~m}^{-2} \mathrm{~h}^{-1}$ were identified with real and synthetic urine compared to $20 \mathrm{~kg} \mathrm{~m}^{-2} \mathrm{~h}^{-1}$ with blackwater(Figure $4 \mathrm{~b}$ ).

Previous authors have observed that organic fouling introduces wetting (Gryta, 2008; Goh et al. 2013) whereas this study emphasises the positive 'self-healing' role of particle deposition in enhancing selective separation for distillation using coarse pore membranes. The impact of fouling is strongly dependent upon the chemical composition and concentration of foulants. For example, Goh et al (2013) demonstrated that membrane distillation was less susceptible to biologically derived organics. Whilst stables fluxes were sustained to high concentration factors in this study (Figure $2, \mathrm{C}_{f}$ $>2.5$ ), partial wetting was eventually observed for the $0.1 \mu \mathrm{m}$ membrane by an increase in permeate COD to $0.71 \mathrm{gCOD} \mathrm{L}^{-1}$ (Figure 2b). Kamranvand et al. (2018) did not evidence breakthrough during the membrane distillation of urine using a coarse pore size membrane. Urine primarily comprises low molecular weight organics that reduce surface tension of the fluid (55 mN m-1 versus $72.8 \mathrm{mN} \mathrm{m}-1$ for water) but this alone is not significant enough to effect a high degree of pore wetting (Kamranvand et al., 2018). In this study, we propose that it is the deposition of high molecular weight organics, colloids and particles introduced from the faecal fraction in the blackwater that reduces the membrane hydrophobicity, leading to breakthrough (Rehman et al., 2019). Whilst wetting was observed, the permeate quality and consistency in flux exhibited at high concentration factors in blackwater, which is forty times more concentrated than medium strength municipal sewage, suggests that with the intervention of upstream pretreatment to mitigate the role of the high molecular weight fraction in surface wetting, a robust solution can be delivered for blackwater treatment.

The retention of pathogens has been rarely studied in membrane distillation thus to establish pathogen rejection, the retention of $E$. coli was evaluated due to its prevalence in the human gut (Katouli, 2010). Blackwater comprising $1.8 \%$ faeces $\mathrm{w} / \mathrm{w}$ was characterised with an average initial E. coli concentration of $\sim 4.75 \times 10^{5} \mathrm{CFU} \mathrm{mL}^{-1}$. Membrane distillation experiments were conducted at $40^{\circ} \mathrm{C}$ as this is close to the optimum growth temperature for $E$. coli, which has a typical size at the stationary phase of $2.0 \mu \mathrm{m}$ in length and $0.25 \mu \mathrm{m}$ width (Yu et al., 2014). For pore sizes below $0.45 \mu \mathrm{m}$, a log reduction value (LRV) of greater than 8.8 was observed (Figure 5), which can be 
ascribed to the selectivity provided by the vapour pressure gradient (Gryta, 2008) together with the size exclusion provided by the membrane. For coarser pore sizes, a lower LRV was established but was consistently above 4 LRV, which is greater than expected based on specific cell size of $E$. Coli but is comparable to faecal coliform rejection of sewage effluent by hydrophobic polypropylene microfiltration membranes of similar pore size $(0.45 \mu \mathrm{m}=\sim 4.8 \log$ reduction, $1.2 \mu \mathrm{m}=\sim 3.3 \log$ reduction; Till et al., 1998; Judd \& Till, 2000). Similar to these authors, we propose the selectivity exhibited by the coarse membrane to have been augmented by the foulant layer.

\subsection{The effect of higher feed temperature on improving permeate quality}

The impact of temperature on permeate quality was studied with the elected pore size of $0.1 \mu \mathrm{m}$ due to the consistently high separation offered by this membrane. As expected higher feed temperatures resulted in enhanced total flux due to the greater vapour pressure gradient (Figure 6a). At feed temperatures of 50 and $60{ }^{\circ} \mathrm{C}$, consistent permeate quality was observed, with rejection exceeding 95, 98 and $98 \%$ for COD, conductivity and ammoniacal nitrogen respectively (Figure 6). This is particularly notable, since this separation was achieved for product recoveries exceeding $70 \%$ (concentration factor, $C_{f},>1.55$ ) from a concentrated organic and particle rich matrix. The lower rejections observed at $40^{\circ} \mathrm{C}$ could be partially explained by the increased residence time due to the constrained permeate flux (Figure 6a) and the reduction in selectivity toward water which is known to occur for vacuum membrane distillation due to the greater sensitivity of water flux to temperature compared to volatile organics and ammonia (Chiam et al., 2013; He et al., 2018; Ding et al., 2006).

The consistent ammonium rejection identified at 50 and $60^{\circ} \mathrm{C}$ is particularly remarkable since the addition of faecal matter to urine is known to increase the total concentration of ammoniacal nitrogen (Udert et al., 2003; Ray et al., 2018). The presence of bacterial urease from the faecal fraction in urine causes an enhancement of the hydrolysis of urea to ammonium according to (Udert et al., 2003; Georges, 1979):

$$
\mathrm{CO}\left(\mathrm{NH}_{2}\right)_{2}+3 \mathrm{H}_{2} \mathrm{O} \rightarrow 2 \mathrm{NH}_{4}^{+}+\mathrm{OH}^{-}+\mathrm{HCO}_{3}{ }^{-} \quad \text { (Equation 1) }
$$

The formation of bicarbonate along with ammonium increases solution $\mathrm{pH}$, which in turn shifts the ammonia-ammonium equilibrium toward volatile ammonia (Ray et al., 2018) which can transition across the membrane (EL-Bourawi et al., 2007; Duong et al., 2013). In this study, whilst a distinct increase in $\mathrm{pH}$ was observed at $40^{\circ} \mathrm{C}$, the increase in $\mathrm{pH}$ was comparatively less at higher feed temperatures (Appendix B), and has been similarly observed by other authors (Zhou et al., 2017). The percentage of ammoniacal nitrogen 
present as free ammonia at a particular $\mathrm{pH}$ can be predicted from the acidic dissociation constants of ammonium (Bates \& Pinching, 1949). For example, at $40^{\circ} \mathrm{C}$ an average $\mathrm{pH}$ of 8.9 was observed for the feed (Figure B-1) resulting in around $55.4 \%$ of ammoniacal nitrogen present as free ammonia $\left(\mathrm{NH}_{3}\right)$. When the temperature increased to $50{ }^{\circ} \mathrm{C}$, the $\mathrm{pH}$ reached an average of 8.3 relating to $36.7 \%$ free ammonia and was suppressed further at $60{ }^{\circ} \mathrm{C}$ resulting in an average $\mathrm{pH}$ of 7.9 and free ammonia of $29.3 \%$. The exact mechanism for mitigating urease activity at temperature is as yet unclear, but is likely to involve either the denaturation of the urease enzyme or the inactivation of urea hydrolysing bacteria at elevated temperatures. Importantly, by operating at higher temperatures, and short residence times (see Appendix C and Zhou et al,. 2017), sustained ammonia separation can be achieved by inhibiting a shift in the ammoniumammonia equilibrium.

The impact of temperature on the rejection of pathogens was studied temporally during VMD at 40 and $50{ }^{\circ} \mathrm{C}$ (Figure 7). At $40^{\circ} \mathrm{C}$, growth of $E$. coli occurred briefly in the feed and then reduced to the limit of detection, whereas at $50^{\circ} \mathrm{C}$, E. coli started to decline from the outset of permeation. Whilst significant growth might not be expected at $50{ }^{\circ} \mathrm{C}$ due to diminished kinetics, the rapid decline in E. coli population was also unforeseen (Noor et al., 2013). Batch experiments with concentrated blackwater without concentration by VMD were undertaken to evaluate $E$. coli inactivation and analysis of the free ammonia concentration at both conditions, based on solution $\mathrm{pH}$ and ammoniacal nitrogen development (Appendix C). At 40 and $50^{\circ} \mathrm{C}$, a reduction in E. coli count was first noted upon reaching a free ammonia concentration of around $200-250 \mathrm{mg} \mathrm{L}^{-1}$. This indicates that an increase in free ammonia induced by urease activity could be contributing to inactivation of the pathogens at relatively low temperature; the free ammonia concentration is in the range that has been shown to induce inhibition for a broader microbial group, across multiple source waters (Jiang et al., 2019). While multiple mechanisms have been postulated, confirmatory evidence for the role of free ammonia inhibition is still required (Jiang et al., 2019), though the response observed is comparable to Pecson et al. (2007) for the inactivation of ascaris eggs in sewage sludge. Importantly though, throughout the duration of permeation, E. coli were not detected above the detection limit in the permeate $\left(0.1 \mathrm{CFU} \mathrm{mL^{-1 }}\right)$; this is particularly noteworthy for analysis at $40{ }^{\circ} \mathrm{C}$ where wetting was observed, as we believe this to be the first evidence of pathogen rejection reported for membrane distillation. For comparison, the impact of elevated feed temperature on E. coli was also studied in batch feed samples (Appendix C) and demonstrated that at a feed temperature 
of $60^{\circ} \mathrm{C}$, the $E$. coli number reduces almost immediately to the method detection limit used (10 CFU mL-1). This demonstrates the complementary effect of operating MD at higher feed-side temperatures, which can achieve significant log credit removal in a single stage process.

\subsection{The effect of the particulate organic fraction on permeate water quality}

Increasing faecal contamination in urine was studied to establish its implications on produced water quality by VMD. To provide a baseline, temporal analysis was undertaken for fresh urine, which demonstrated a pseudo steady-state flux of around $30 \mathrm{~kg} \mathrm{~m}^{-2} \mathrm{~h}^{-1}$ (Figure 8a) at a feed temperature of $60^{\circ} \mathrm{C}$ and was consistent through to a $C_{f}$ exceeding 2 (Figure $8 \mathrm{~b}$ ). This is comparable to the findings of Kamranvand et al. (2018) which indicates that despite the high organic concentration $(3,500 \pm 200 \mathrm{mgCOD}$ $\mathrm{L}^{-1}$ ), this discrete group of low molecular weight compounds including urea and organic acids, do not obviously foul the membrane. An increase in the blackwater particle fraction was facilitated by adding faeces to between 0.4 and $6.7 \% \mathrm{w} / \mathrm{w}$. Whilst initial fluxes were broadly comparable, the rate of flux decline increased for higher faecal particle fractions which confirms earlier observations at a fixed particulate fraction (Figure 4). The most concentrated blackwater $(6.7 \%$ faecal solids $\mathrm{w} / \mathrm{v})$ represents the ratio of urine and faeces typically produced from one person (Mercer et al., 2019), and as this sample was then completely homogenised, it represents the highest organic loading achievable in the liquid phase; introduction of pretreatment will remove this particle fraction in addition to mitigating the extent of mixing (Cruddas et al., 2015; Gryta et al., 2006). However, evaluation of the implications of the faecal particle fraction on permeate quality help to establish process resilience and guide how to best inform engineered design.

Importantly, despite this considerable organic load, the produced water quality demonstrated high separation potential offered by VMD for organics, conductivity and ammonia (Figure 9a), particularly when considering the initial organic concentration within the blackwater which ranged between 3,500 \pm 200 and 25,300 $\pm 2,800 \mathrm{mgCOD} \mathrm{L}^{-1}$, for urine and blackwater comprised of $6.7 \% \mathrm{w} / \mathrm{w}$ faecal particle fraction respectively. For faecal solids concentrations below $0.4 \%$, the permeate COD concentration was below that proposed within the recently released ISO 30500 standard on advanced treatment systems for non-sewered sanitation (COD, $150 \mathrm{mg} \mathrm{L}^{-1}$; International Organization for Standardization, 2018) (Table 1), which would indicate that membrane distillation can withstand some contamination of the particulate organic fraction without initiating wetting. 
The temporal impact of faecal solids concentration on blackwater quality was determined in batch experiments (Appendix D). This evidenced a significant increase in solution $\mathrm{pH}$ following an increase in faecal solids concentration, ostensibly due to the higher proportion of urea hydrolysing bacteria or extracellular enzymatic activity; a trend supported by the large increase in ammoniacal nitrogen observed for the higher faecal solids concentration over time. This provides additional evidence of the relationship between inactivation of $E$. coli (Figure D-1c) and free ammonia concentration (Figure D1d) which was not observed for urine or the more dilute blackwater (0.4\%; Figure D-1c). However, migration of free ammonia was limited during membrane distillation for high solids concentrations, which were operated at $60^{\circ} \mathrm{C}$, rather than $40^{\circ} \mathrm{C}$ used in batch evaluation. We therefore propose that the higher operating temperature for membrane distillation is advantageous since the ammonia-ammonium equilibrium is sustained toward ammonium, independent of the extent of faecal contamination. This resulted in a trend comparable to that for conductivity (Table 1, Figure 9b), in which ammonium rejection exceeded $95 \%$ removal for all faecal solids concentrations, equivalent to $200 \mathrm{mgNH}_{4}{ }^{+}-\mathrm{N} \mathrm{L}^{-1}$ in the permeate (Table 1). This is high relative to the permeate quality experienced in conventional sewage treatment due to the absence of flushwater which imposes dilution (Mercer et al., 2019). In recognition of this concentrative effect, the ISO30500 standard for discharge places a requirement to achieve a $70 \%$ reduction in nitrogen (International Organisation for Standardization, 2018), which membrane distillation can safely achieve (Table 1) with a modest feed temperature.

\section{Conclusions}

This study demonstrates how membrane pore size and temperature can be used in membrane distillation to recover high quality water from blackwater sufficient to meet international standards for discharge:

- Significant log reduction values for the enteric pathogen E. Coli were demonstrated with membrane distillation due to a combination of size exclusion, and the vapourliquid equilibrium used to transport water. This can be complemented by modest feed temperatures $\left(>60^{\circ} \mathrm{C}\right)$ which advantage log reduction values through pathogen inactivation.

- Smaller pore size membranes permit higher liquid entry pressures in blackwater $(0.1$ $\mu \mathrm{m})$ sufficient to sustain the liquid-vapour interface, which enables consistent organic separation efficiency, such that permeate quality equivalent to the ISO30500 standard (150 mgCOD L-1) can be achieved. 
- Ammonia separation is an acknowledged challenge in membrane distillation. The mechanism for separation was shown to be complex, where the ammonium concentration and the liberation of free-ammonia was dependent upon residence time, feed temperature and faecal particle concentration. Whilst the liberation of free ammonia likely contributed to $E$. Coli inactivation at lower temperatures, it is deleterious to permeate quality. As such, higher feed temperatures are recommended which facilitate $E$. Coli inactivation whilst simultaneously retarding the shift in ammonium-ammonia equilibrium. Therefore, enabling consistently high ammonium rejection; where the slower kinetics of ammonia and bicarbonate formation as a result of enzyme denaturing or thermal inactivation at higher temperatures suggest operation could be complemented by shorter residence times to provide further resilience to ammonium rejection.

The role of the particle fraction (provided by faecal contamination of blackwater) on water productivity and permeate quality was also established:

- For coarser pore sizes, the particle fraction produces a cake layer on the membrane which introduces a fourth resistance to mass transfer, but re-establishes the vapourliquid equilibrium, subsequently improving product water quality. However, small pore size membranes were capable of achieving comparable water productivities and with more stable product water quality.

- The particle fraction is primarily responsible for the reduction in flux due to the reduction in mass transfer, whilst the low molecular weight inorganic and organic fractions do not affect permeate flux.

- Despite the high concentration of low molecular compounds and the low surface tension of solution, membrane wetting can be avoided in the absence of the particle fraction, which sustain production of high quality permeate. As such, membrane distillation should be supplemented with upstream engineering interventions to separate the particle fraction.

\section{Acknowledgements}

This publication is based on research funded by the Bill \& Melinda Gates Foundation (grant number OPP1149204). The findings and conclusions contained within are those of the authors and do not necessarily reflect positions or policies of the funders. Data underlying this paper can be accessed at: (https://doi.org/ 10.17862/cranfield.rd.13073219) 


\section{References}

Alkhudhiri, A., Darwish, N. \& Hilal, N. (2012). Membrane distillation: A comprehensive review. Desalination, 287, 2-18. doi: 10.1016/j.desal.2011.08.027

Bazilian, M., Nussbaumer, P., Rogner, H.H., Brew-Hammond, A., Foster, V., Pachauri, S., Williams, E., Howells, M., Niyongabo, P., Musaba, L., Gallachóir, B. ó, Radka, M. \& Kammen, D.M. (2012). Energy access scenarios to 2030 for the power sector in subSaharan Africa. Utilities Policy, 20,1-16. doi: 10.1016/j.jup.2011.11.002

Banat, F., Jwaied, N., Rommel, M., Koschikowski, J. \& Wieghaus, M. (2007). Desalination by a "compact SMADES" autonomous solar-powered membrane distillation unit. Desalination, 217, 29-37. doi:10.1016/j.desal.2006.11.028

Bates, R., Pinching, G. (1949). Acidic dissociation constant of ammonium ion at 0 to 50 C, and the base strength of ammonia, J. Res. Natl. Bur. Stand., 42, 419-430. doi: 10.6028/jres.042.037.

Bellona, C., Drewes, J. E., Xu, P., Amy, G. (2004). Factors affecting the rejection of organic solutes during NF/RO treatment-aliterature review. Water Res., 12, 2795-2809. doi: $10.1016 /$ j.watres.2004.03.034

Chen, S \& Ravallion, M. (2010). The developing world is poorer than we thought, but no less successful in the fight against poverty. Quarterly Journal of Economics, 1577-1625. doi: 10.1162/qjec.2010.125.4.1577

Chiam, C-K. \& Sarbatly, R. (2013). Vacuum membrane distillation processes for aqueous solution treatment-A review. Chemical Engineering and Processing: Process Intensification, 74, 247-54. doi:10.1016/j.cep.2013.10.002

Christiaens, M.E.R., Udert, K.M., Arends, J.B.A., Huysman, S., Vanhaecke, L., McAdam, E. \& Rabaey, K. (2019). Membrane stripping enables effective electrochemical ammonia recovery from urine while retaining microorganisms and micropollutants. Water Research, 150, 349-357. doi:10.1016/j.watres.2018.11.072

Cruddas, P.H., McAdam, E.J., Kolios, A., Parker, A., Williams, L., Martin, B., Buckley, C.A. \& Tyrrel, S. (2015). Biosolids Management Within the Nano Membrane Toilet Separation, Thickening and Dewatering. WEF/IWA Residuals and Biosolids Conference. Washington DC, US.

Ding, Z., Liu, L., Li, Z., Ma, R. \& Yang, Z. (2006). Experimental study of ammonia removal from water by membrane distillation (MD): The comparison of three configuration. 
Journal of Membrane Science, 286, 93-103. doi: 10.1016/j.memsci.2006.09.015

Dufour, A. (1977). Escherichia coli: The Fecal Coliform. in Bacterial Indicators/Health Hazards Associated with Water. ed. A. Hoadley and B. Dutka (West Conshohocken, PA: ASTM International), 48-58. doi: 10.1520/STP34817S

Duong, T., Xie, Z., Ng, D. \& Hoang, M. (2013). Ammonia removal from aqueous solution by membrane distillation. Water and Environment Journal, 27, 425-434. doi: 10.1111/j.1747-6593.2012.00364.x

EL-Bourawi, M.S., Khayet, M., Ma, R., Ding, Z., Li, Z. \& Zhang, X. (2007). Application of vacuum membrane distillation for ammonia removal. Journal of Membrane Science, 301, 200-209. doi: 10.1016/j.memsci.2007.06.021

Eykens, L., De Sitter, K., Dotremont, C., Pinoy, L. \& Van der Bruggen, B. (2016). How To Optimize the Membrane Properties for Membrane Distillation: A Review. Industrial \& Engineering Chemistry Research, 55, 9333-9343. doi: 10.1021/acs.iecr.6b02226

Franken, A.C.M., Nolten, J.A.M., Mulder, M.H. V, Bargeman, D. \& Smolders, C.A. (1987). Wetting criteria for the applicability of membrane distillation. Journal of Membrane Science, 33, 315-328. doi: 10.1016/S0376-7388(00)80288-4

Georges, J. (1979). Determination of ammonia and urea in urine and of urea in blood by use of an ammonia-selective electrode. Clinical Chemistry, 25, 1888-1890. doi: 10.1093/clinchem/25.11.1888

Goh, S., Zhang, J., Liu, Y. \& Fane, A.G. (2013). Fouling and wetting in membrane distillation (MD) and MD-bioreactor (MDBR) for wastewater reclamation. Desalination, 323, 39-47. doi: 10.1016/j.desal.2012.12.001

Gryta, M., Tomaszewska, M. \& Karakulski, K. (2006). Wastewater treatment by membrane distillation. Desalination, 198, 67-73. doi:10.1016/j.desal.2006.09.010

Gryta, M. (2008). Fouling in direct contact membrane distillation process. Journal of Membrane Science, 325, 383-394. doi: 10.1016/j.memsci.2016.11.072

Gryta, M. (2010). Desalination of thermally softened water by membrane distillation process. Desalination, 257, 30-35. doi: 10.1016/j.desal.2010.03.012

He, Q., Tu, T., Yana, S., Yang, X., Duke, M., Zhang, Y. \& Zhao, S. (2018). Relating water vapor transfer to ammonia recovery from biogas slurry by vacuum membrane distillation. Separation and Purification Technology, 191, 182-191. doi: 10.1016/j.seppur.2017.09.030 
Holler, S. (2003, May 1) Decentralised infrastructure saves system costs, produces biogas energy. from https://www.waterworld.com/international/wastewater/article/16200433/decentralisedinfrastructure-saves-system-costs-produces-biogas-energy

Hutton, G. (2013). Global costs and benefits of drinking-water supply and sanitation interventions to reach the MDG target and universal coverage. Journal of Water and Health, 11, 1-12. doi: 10.2166/wh.2012.105.

IEA (2011). World Energy Outlook 2011, OECD Publishing, Paris. doi: 10.1787/weo2011-en

International Organization for Standardization. (2018). Non-sewered sanitation systems - Prefabricated integrated treatment units - General safety and performance requirements for design and testing (ISO 30500:2018(E))

Jiang, Y., McAdam, E., Zhang, Y., Heaven, S., Banks, C. \& Longhurst, P. (2019) Ammonia inhibition and toxicity in anaerobic digestion: A critical review. Journal of Water Process Engineering, 32, 100899. doi:10.1016/j.jwpe.2019.100899

Judd, S.J., \& Till, S.W. (2000). Bacterial rejection in crossflow microfiltration of sewage. Desalination, 127, 251-260. doi: 10.1016/S0011-9164(00)00014-X

Kamranvand, F., Davey, C.J., Sakar, H., Autin, O., Mercer, E., Collins, M., Williams, L., Kolios, A., Parker, A., Tyrrel, S., Cartmell, E. \& McAdam, E.J. (2018). Impact of fouling, cleaning and faecal contamination on the separation of water from urine using thermally driven membrane separation. Separation Science and Technology, 53, 1372-1382. doi: $10.1080 / 01496395.2018 .1433688$

Kasenow, M. (1997). Applied Ground-water Hydrology and Well Hydraulics (2nd ed.). Highlands Ranch, CO.

Khan E. U. \& Martin. A. R. (2015). Optimization of hybrid renewable energy polygeneration system with membrane distillation for rural households in Bangladesh. Energy, 93, 1116-1127. doi: 10.1016/j.energy.2015.09.109

Lee, S \& Lueptow, R. M. (2001). Reverse osmosis filtration for space mission wastewater: membrane properties and operating conditions. Journal of Membrane Science, 181, 77-90. doi: 10.1016/S0376-7388(00)00553-6

Madaeni, S.S. (1999). The application of membrane technology for water disinfection. Water Research, 33, 301-308. doi: 10.1016/S0043-1354(98)00212-7 
Maurer, M., Pronk, W., Larsen, T.A. (2006). Treatment processes for source-separated urine. Water Res., 17, 3156-3166. doi: 10.1016/j.watres.2006.07.012

Mercer, E., Cruddas, P., Williams, L., Kolios, A., Parker, A., Tyrrel, S., Cartmell, E., Pidou, M. \& McAdam, E.J. (2016). Selection of screw characteristics and operational boundary conditions to facilitate post-flush urine and faeces separation within single household sanitation systems. Environmental Science: Water Research \& Technology, 2, 953-964. doi: 10.1039/C6EW00170J

Mercer, E., Davey, C.J., Azzini, D., Eusebi, A.L., Tierney, R., Williams, L., Jiang, Y., Parker, A., Kolios, A., Tyrrel, S., Cartmell, E., Pidou, M. \& McAdam, E.J. (2019). Hybrid membrane distillation reverse electrodialysis configuration for water and energy recovery from human urine: An opportunity for off-grid decentralised sanitation. Journal of Membrane Science, 584, 343-352. doi:10.1016/j.memsci.2019.05.010

Müller, T., Walter, B., Wirtz, A. \& Burkovski, A. (2006). Ammonium toxicity in bacteria. Current Microbiology, 52, 400-406. doi: 10.1007/s00284-005-0370-x

Naidu, G., Jeong, S., Kim, S-J., Kim, In S. \& Vigneswaran, S. (2014). Organic fouling behavior in direct contact membrane distillation. Desalination, 347, 230-239. doi: 10.1016/j.desal.2014.05.045

Noor, R., Islam, Z., Munshi, S.K. \& Rahman, F. (2013). Influence of temperature on Escherichia coli growth in different culture media. Journal of Pure and Applied Microbiology, 7, 899-904.

Putnam, D.F. (1971). Composition and concentrative properties of human urine. McDonnell Douglas Astronautics Company - Western Division.

Rácz, G., Kerker, S., Kovács, Z., Vatai, G., Ebrahimi, M. \& Czermak, P. (2014). Theoretical and experimental approaches of liquid entry pressure determination in membrane distillation processes. Periodica Polytechnica Chemical Engineering, 58, $81-$ 91. doi: 10.3311/PPch.2179

Ray, H., Saetta, D. \& Boyer, T.H. (2018). Characterization of urea hydrolysis in fresh human urine and inhibition by chemical addition. Environmental Science: Water Research \& Technology, 4, 87-98. doi: 10.1039/C7EW00271H

Rehman, W.U., Muhammad, A., Younas, M., Wu, C., Hu, Y. \& Li, J. (2019). Effect of membrane wetting on the performance of PVDF and PTFE membranes in the concentration of pomegranate juice through osmotic distillation. Journal of Membrane Science, 584, 66-78. doi: 10.1016/j.memsci.2019.04.042 
Rezaei, M., Warsinger, D.M., Lienhard V, J.H., Duke, M.C., Matsuura, T. \& Samhaber, W.M. (2018). Wetting phenomena in membrane distillation: Mechanisms, reversal, and prevention. Water Research, 139, 329-352. doi: 10.1016/j.watres.2018.03.058

Rose, C., Parker, A., Jefferson, B. \& Cartmell, E. (2015). The Characterization of Feces and Urine: A Review of the Literature to Inform Advanced Treatment Technology. Critical Reviews in Environmental Science and Technology, 45, 1827-1879. doi: 10.1080/10643389.2014.1000761

Smolders, K. \& Franken, A.C.M. (1989). Terminology for Membrane Distillation. Desalination, 72, 249-262. doi: 10.1016/0011-9164(89)80010-4

Strauss, M. \& Montangero, A. (2002). Feacal Sludge Management Review of Practices, Problems and Initiatives. EAWAG/SANDEC.

Tijing, L.D., Woo, Y.C., Choi, J-S., Lee, S., Kim, S-H. \& Shon, H.K. (2015). Fouling and it's control in membrane distillation-A review. Journal of Membrane Science, 475, 215244. doi: 10.1016/j.memsci.2014.09.042

Till, S.W., Judd, S.J. \& McLoughlin, B. (1998). Reduction of faecal coliform bacteria in sewage effluents using a microporous polymeric membrane. Water Research, 32, 14171422. doi: 10.1016/S0043-1354(97)00344-8

Tillett, T. (2013). Pit Latrines and Groundwater Contamination: Negative Impacts of a Popular Sanitation Method. Science Selections, 121, 5, 169. doi: 10.1289/ehp.121-a169 Tilley, E., Ulrich, L., Lüthi, C., Reymond, Ph., \& Zurbrügg, C. (2014). Compendium of Sanitation Systems and Technologies (2 ed.). Dübendorf, Switzerland: Swiss Federal Institute of Aquatic Science and Technology (Eawag).

Udert, K.M., Larsen, T.A., Biebow, M. \& Gujer, W. (2003). Urea hydrolysis and precipitation dynamics in a urine-collecting system. Water Research, 37, 2571-2582. doi: 10.1016/S0043-1354(03)00065-4

van Voorthuizen, E., Zwijnenburg, A., van der Meer, W. \& Temmink, H. (2008). Biological black water treatment combined with membrane separation. Water Research, 42, 43344340. doi: 10.1016/j.watres.2008.06.012

WASHCost. (2012). The cost of sustaining sanitation services for 20 years can be 5-20 times the cost of building a latrine. WASHCost global infosheets, 2, The Hague, NL.

Winter, D., Koschikowski, J., Düver, D., Hertel, P. \& Beuscher, U. (2013). Evaluation of MD process performance: Effect of backing structures and membrane properties under 
different operating conditions. Desalination, 323, 120-133. doi: 10.1016/j.desal.2013.04.007

Young, T. (1805). An essay on the cohesion of fluids. Philosophical Transactions of the Royal Society of London, 95, 65-87. doi: 10.1098/rspl.1800.0095

Yu, A.C.S., Loo, J.F.C., Yu, S., Kong, S.K. \& Chan, T.-F. (2014). Monitoring bacterial growth using tunable resistive pulse sensing with a pore-based technique. Applied Microbiology and Biotechnology, 98, 855-862. doi: 10.1007/s00253-013-5377-9

Zhao, Z.-P., Xu, L., Shang, X. \& Chen, K. (2013). Water regeneration from human urine by vacuum membrane distillation and analysis of membrane fouling characteristics. Separation and Purification Technology, 118, 369-376. doi: 10.1016/j.seppur.2013.07.021

Zhou, X., Li, Y., Li, Z., Xi, Y., Nazim Uddin, S.M. \& Zhang, Y. (2017). Investigation on microbial inactivation and urea decomposition in human urine during thermal storage. Journal of Water Sanitation and Hygiene for Development, 7, 378-386. doi: 10.2166/washdev.2017.142 




Figure 1. Schematic of the experimental set-up used in all vacuum membrane distillation experiments. 

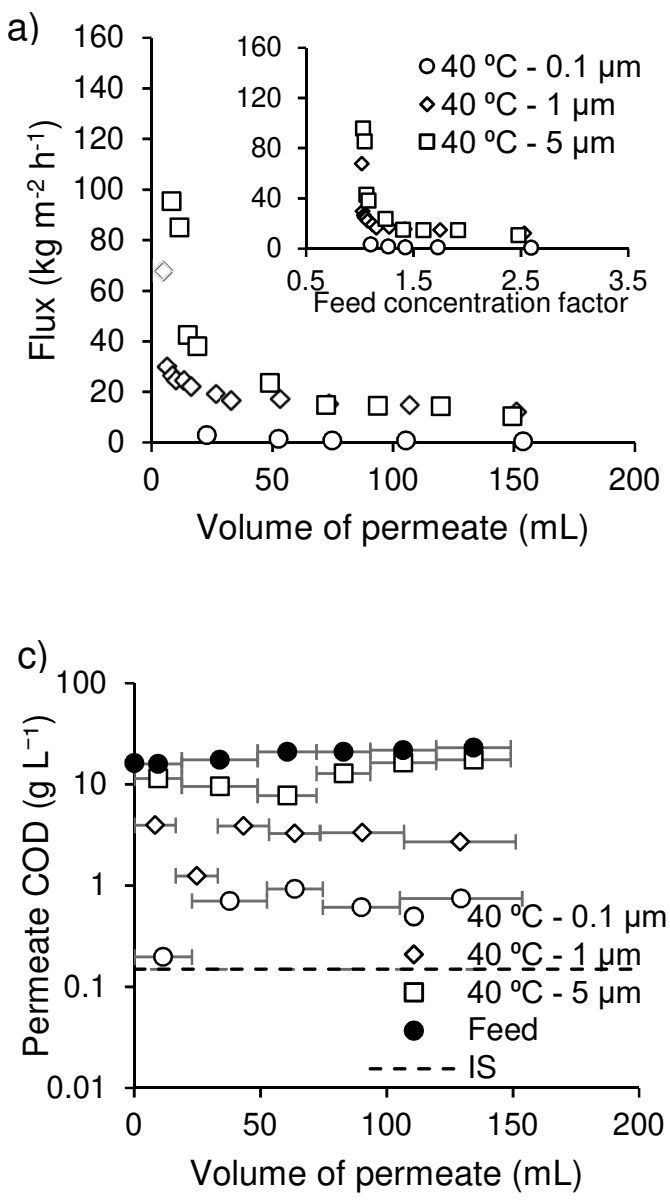

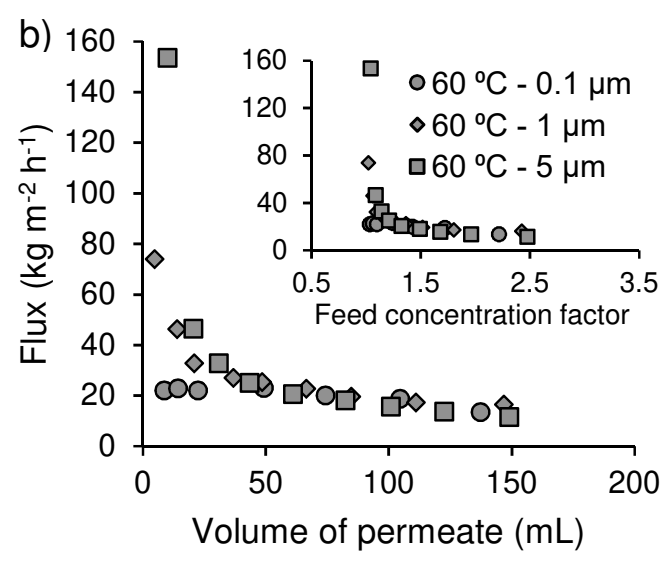

d)

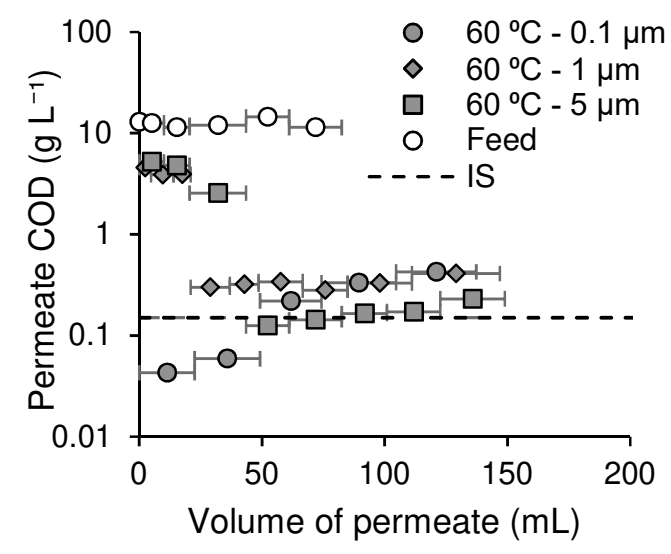

Figure 2. Clean water separation from feedwater (1.8\% faecal matter) using vacuum membrane distillation $\left(0.1,1\right.$, and $5 \mu \mathrm{m}$ PTFE membrane) at 40 and $60^{\circ} \mathrm{C}$ : a) flux analysis at $40^{\circ} \mathrm{C}$, b) flux analysis at $60^{\circ} \mathrm{C}$, flux $v s$ feed concentration factor (concentration factor = initial feed volume / retentate volume), c) permeate COD (COD IS (ISO Standard) $=150 \mathrm{mg} \mathrm{L}^{-1}$ ) at $40^{\circ} \mathrm{C}$, and d) permeate COD at $60^{\circ} \mathrm{C}$. Horizontal error bars indicate time periods permeate samples were collected over. 


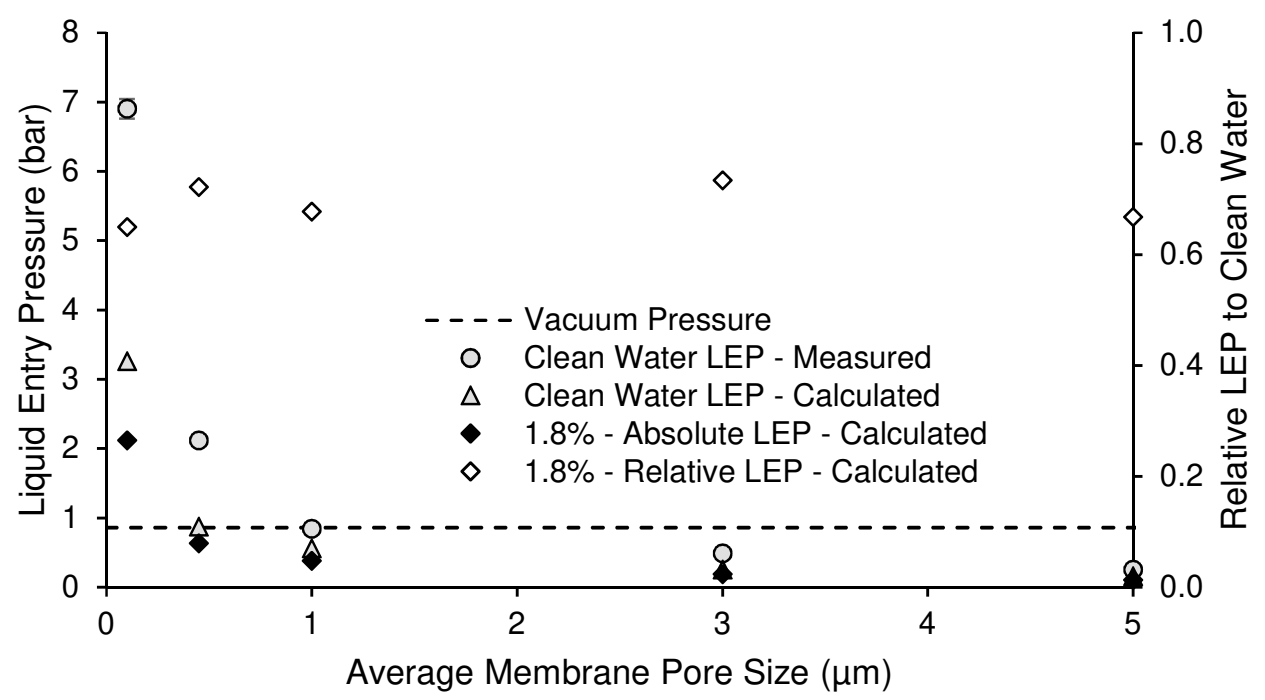

Figure 3. Analysis of liquid entry pressure (LEP) (absolute value for blackwater treatment, and relative value to the clean water $L E P$ ) for $0.1,0.45,1,3$, and $5 \mu \mathrm{m}$ PTFE membrane for the filtration of clean water, and concentrated blackwater comprised of $1.8 \mathrm{wt}$. \% faecal matter.

(a)

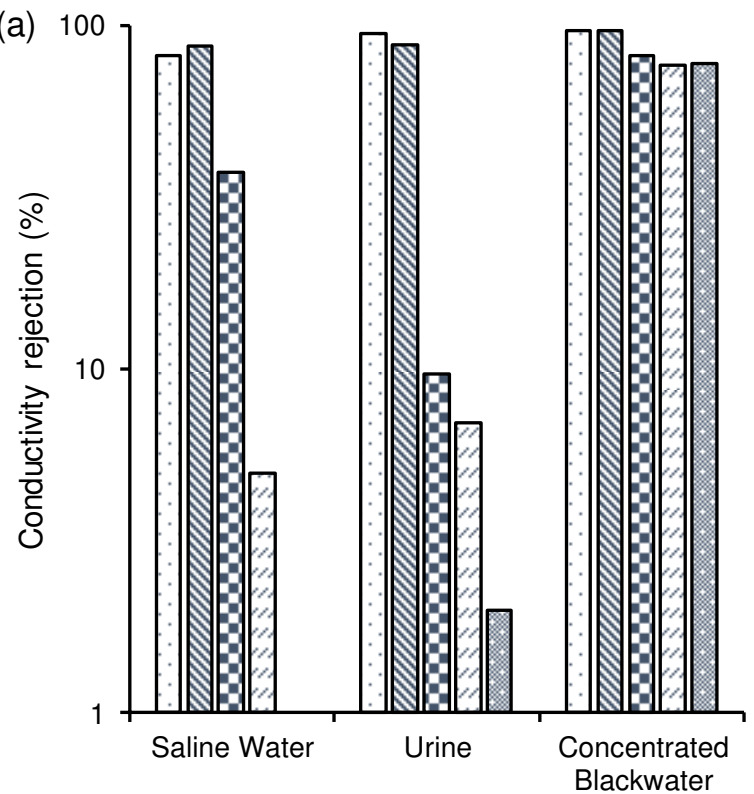

$\square 0.1 \mu \mathrm{m}$

$\nabla 0.45 \mu \mathrm{m}$

$\square 1 \mu \mathrm{m}$

$\square 3 \mu \mathrm{m}$

口 $5 \mu \mathrm{m}$

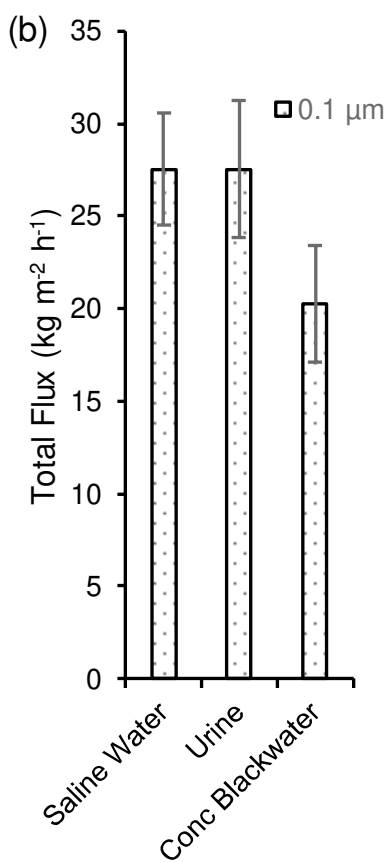

Figure 4. (a) Analysis of conductivity rejection from saline water (comprising $11.55 \mathrm{gl}^{-1} \mathrm{NaCl}$ in DI water), urine, and concentrated blackwater (1.8 wt. \% faecal matter), at $60{ }^{\circ} \mathrm{C}$ using 0.1, 0.45, 1, 3, and $5 \mu \mathrm{m}$ PTFE membrane (b) average flux data for the $0.1 \mu \mathrm{m}$ membrane (error bars show $\pm S D$ during experiment). 


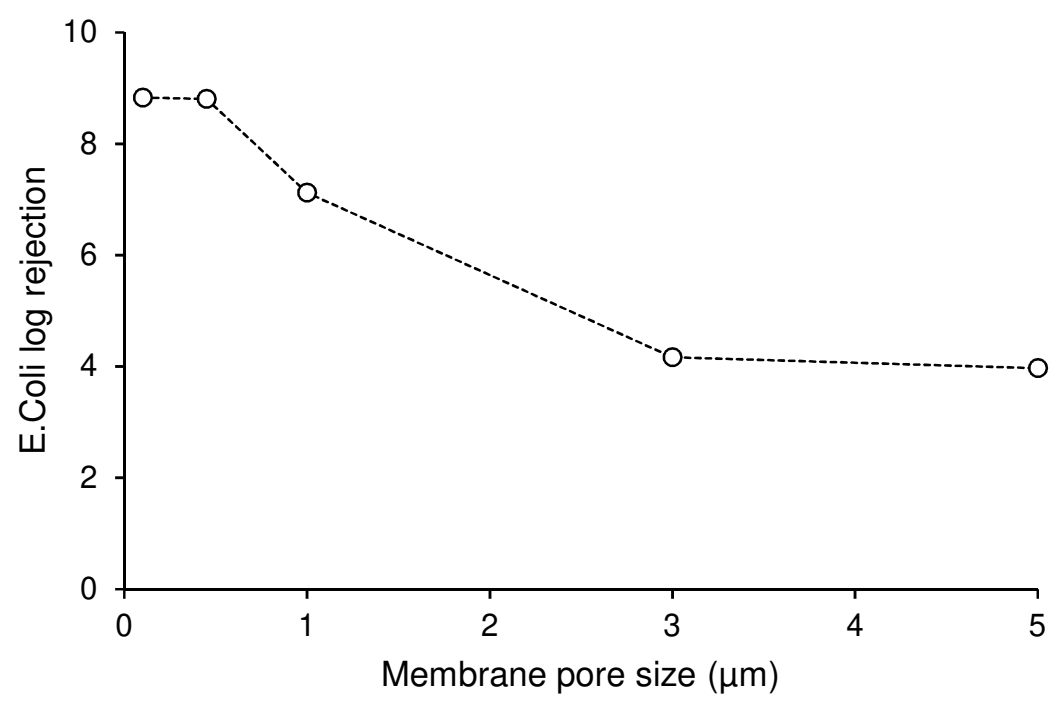

Figure 5. Pathogen rejection determined for membrane distillation with each pore size at $40^{\circ} \mathrm{C}$ feed temperature. Feed, blackwater comprising 1.8\% faecal matter; Vacuum, 140 mbar; Crossflow velocity, 0.1 $m s^{-1}$.

(a)

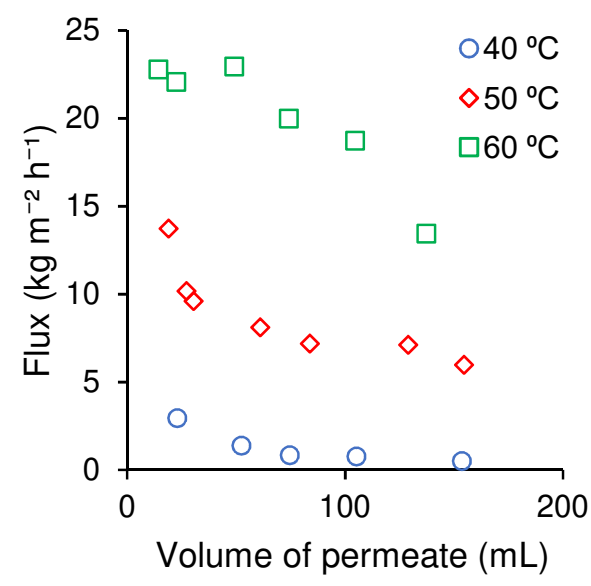

(c)

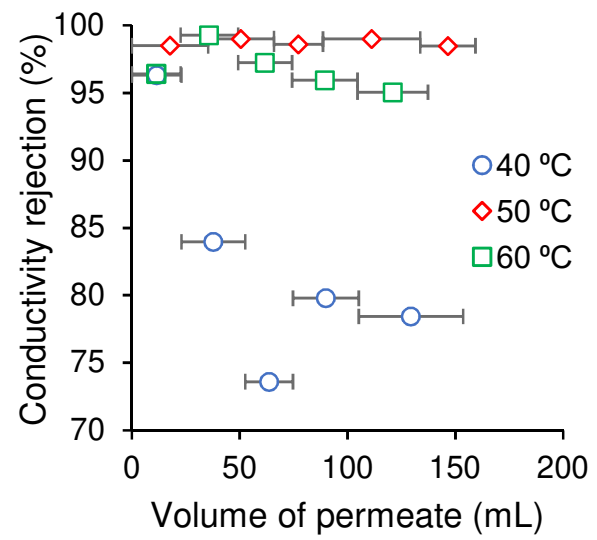

(b)

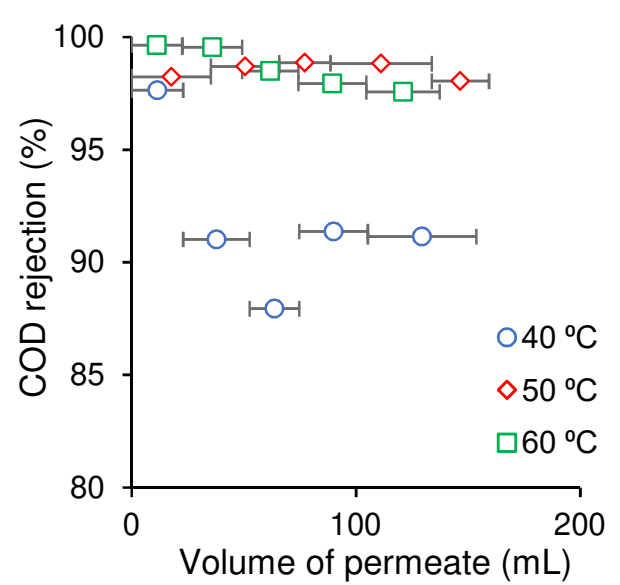

(d)

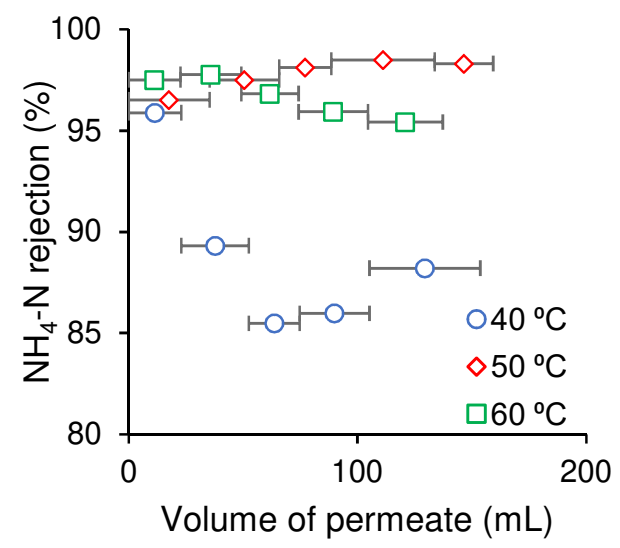

Figure 6. Impact of temperature $\left(40-60^{\circ} \mathrm{C}\right)$ on water recovery from blackwater using membrane distillation. Initial feed comprises $1.8 \%$ wt. faecal matter; Membrane, $0.1 \mu \mathrm{m}$. (a) Water flux; (b-d) COD, conductivity 
and ammonium rejection. Horizontal error bars indicate time periods permeate samples were collected over.

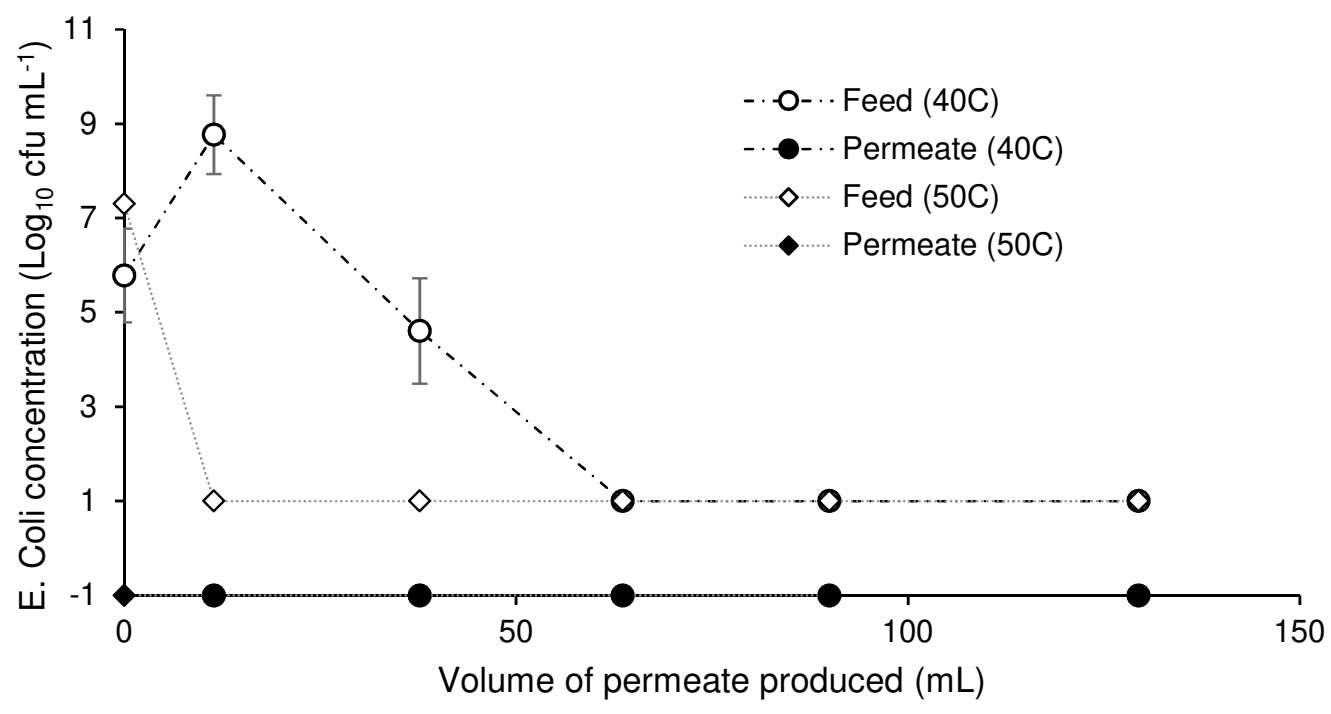

Figure 7. Impact of temperature $\left(40-60^{\circ} \mathrm{C}\right)$ on pathogen rejection during water recovery from blackwater using membrane distillation. Feed comprises 1.8\% wt. faecal matter; Membrane, $0.1 \mu \mathrm{m}$. Limit of detection in feed and permeate, 10 and $0.01 \mathrm{cfu} \mathrm{mL}^{-1}$ respectively.

a)

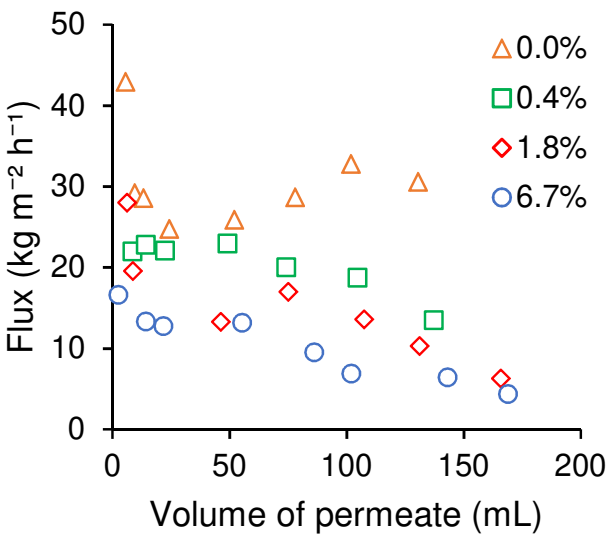

b)

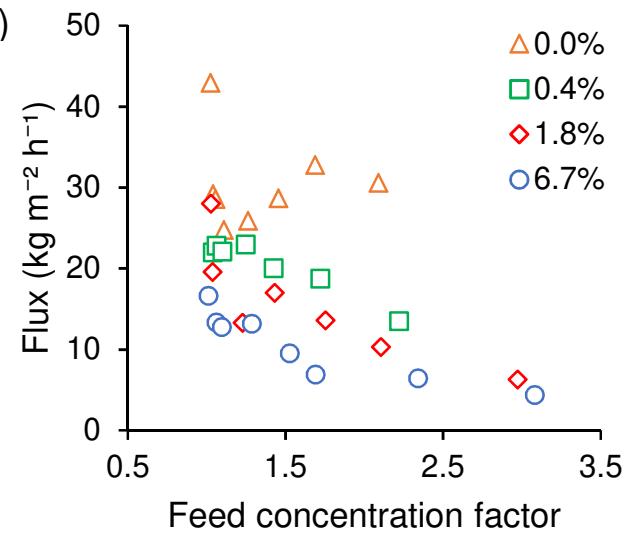

Figure 8 Impact of faecal concentration (0 to $6.7 \%$ wt., where $0 \%$ is pure urine) in blackwater on water recovery and permeate quality in membrane distillation. Initial feed condition: Feedwater temperature, $60^{\circ} \mathrm{C}$; membrane, $0.1 \mu \mathrm{m}$ PTFE membrane. (a) flux vs volume of permeate; b) flux vs feed concentration factor (concentration factor $=$ initial feed volume / retentate volume) 
a)

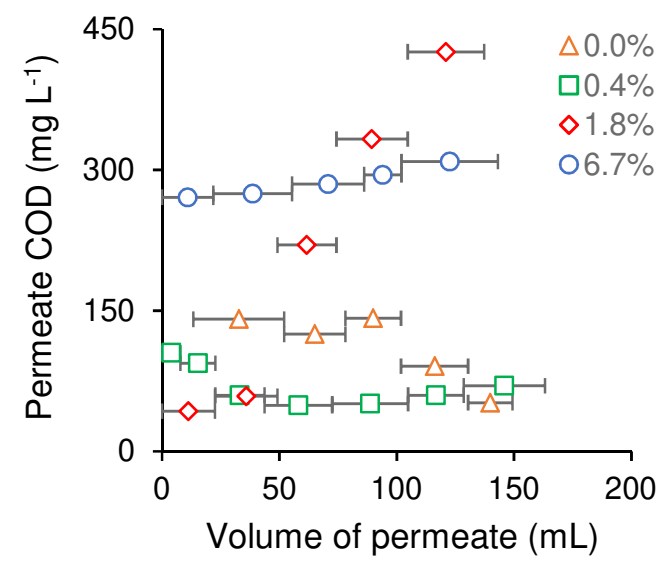

b)

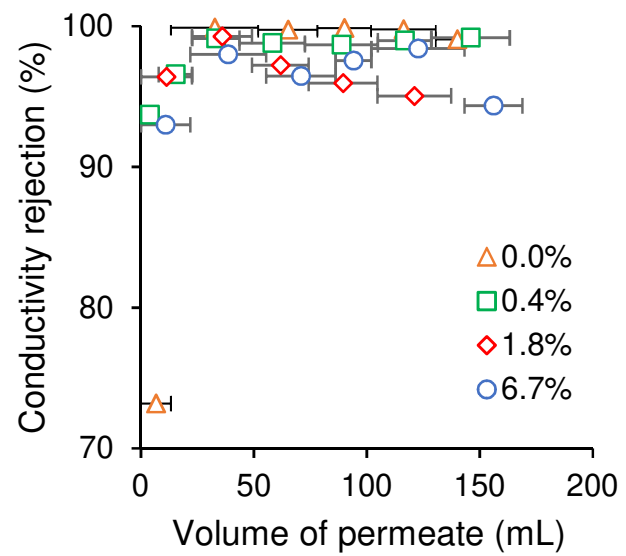

Figure 9. Impact of faecal concentration (0 to $6.7 \%$ wt., where $0 \%$ is pure urine) in blackwater on water recovery and permeate quality in membrane distillation. Initial feed condition: Feedwater temperature, $60^{\circ} \mathrm{C}$; membrane, $0.1 \mu \mathrm{m}$ PTFE membrane. a) permeate COD; b) conductivity rejection, and c) ammoniacal nitrogen rejection. Horizontal error bars indicate time periods permeate samples were collected over. 
Table 1. Impact of faecal solids concentration on membrane distillation of blackwater

\begin{tabular}{|c|c|c|c|c|c|c|c|c|c|c|}
\hline \multirow{2}{*}{$\begin{array}{c}\text { Faecal } \\
\text { solids } \\
\text { concn. } \\
(\%)\end{array}$} & \multicolumn{3}{|c|}{ Blackwater Feed } & \multicolumn{3}{|c|}{ Permeate } & \multicolumn{2}{|c|}{ Removal efficiency } & \multicolumn{2}{|c|}{ ISO30500' } \\
\hline & $\begin{array}{l}\text { COD } \\
\left(g^{-1}\right)\end{array}$ & $\begin{array}{l}\mathrm{NH}_{4}-\mathrm{N} \\
\left(\mathrm{g} \mathrm{L}^{-1}\right)^{\mathrm{a}}\end{array}$ & $\begin{array}{l}\text { Conductivity } \\
\left(\mathrm{mS} \mathrm{cm}^{-1}\right)\end{array}$ & $\begin{array}{l}\text { COD } \\
\left(g^{-1}\right)\end{array}$ & $\begin{array}{l}\mathrm{NH}_{4}-\mathrm{N} \\
\left(\mathrm{g} \mathrm{L}^{-1}\right)^{\mathrm{a}}\end{array}$ & $\begin{array}{l}\text { Conductivity } \\
\left(\mathrm{mS} \mathrm{cm}^{-1}\right)\end{array}$ & $\begin{array}{l}\text { COD } \\
(\%)^{b}\end{array}$ & $\begin{array}{c}\mathrm{NH}_{4}-\mathrm{N} \\
(\%)^{\mathrm{a}}\end{array}$ & $\begin{array}{c}\mathrm{NH}_{4}-\mathrm{N} \\
(70 \% \\
\text { reduction) }\end{array}$ & $\begin{array}{c}\text { COD } \\
\left(150 \mathrm{mg} \mathrm{L}^{-1}\right)\end{array}$ \\
\hline 0.0 & $3.5 \pm 0.2$ & $0.10 \pm 0.03$ & $8.00 \pm 2.41$ & $0.14 \pm 0.03$ & $0.006 \pm 0.004$ & $0.03 \pm 0.02$ & $96.0 \pm 0.6$ & $94.2 \pm 2.4$ & $\checkmark$ & $\checkmark$ \\
\hline 0.4 & $4.8 \pm 0.5$ & $0.19 \pm 0.05$ & $8.46 \pm 2.23$ & $0.10 \pm 0.03$ & $0.011 \pm 0.004$ & $0.55 \pm 0.12$ & $97.9 \pm 0.4$ & $94.4 \pm 0.6$ & $\checkmark$ & $\checkmark$ \\
\hline 1.8 & $8.8 \pm 1.3$ & $0.45 \pm 0.19$ & $13.3 \pm 2.92$ & $0.22 \pm 0.01$ & $0.012 \pm 0.005$ & $0.50 \pm 0.21$ & $99.5 \pm 0.1$ & $97.4 \pm 0.1$ & $\checkmark$ & $\checkmark$ \\
\hline 6.7 & $25.3 \pm 2.8$ & $0.91 \pm 0.31$ & $12.3 \pm 3.81$ & $0.27 \pm 0.05$ & $0.175 \pm 0.036$ & $1.16 \pm 0.29$ & $98.9 \pm 0.1$ & $80.8 \pm 2.9$ & $\checkmark$ & $x$ \\
\hline
\end{tabular}

a Values based on initial data; feedwater dynamics studied in batch (See Appendices). ${ }^{b}$ Based on initial data, i.e. does not consider concentration that occurs in the bulk during distillation. "ISO standard developed to ensure safe practice for single household sanitation technologies. 


\section{Appendices}

\section{Appendix A - Membrane material characteristics}

Table A1. Membrane material details of PTFE membranes supplied by Cobetter Filtration Equipment Co.,Ltd. Values in brackets represent the standard deviation of the measured values of at least three repeats.

\begin{tabular}{|c|c|c|c|c|c|c|c|c|c|}
\hline $\begin{array}{l}\text { Manufacturer } \\
\text { Stated Pore Size }\end{array}$ & $\begin{array}{l}\text { Smallest } \\
\text { Measured }\end{array}$ & $\begin{array}{l}\text { Average } \\
\text { Measured }\end{array}$ & Largest & $\begin{array}{l}\text { Measured } \\
\text { Porosity }\end{array}$ & $\begin{array}{l}\text { Measured } \\
\text { Water }\end{array}$ & $\begin{array}{l}\text { Manufacturer } \\
\text { Stated LEP }\end{array}$ & $\begin{array}{l}\text { Measured } \\
\text { LEP* }^{*}\end{array}$ & $\begin{array}{l}\text { Manufacturer } \\
\text { Stated }\end{array}$ & $\begin{array}{l}\text { Measured } \\
\text { Thickness }\end{array}$ \\
\hline$(\mu \mathrm{m})$ & $\begin{array}{l}\text { Pore Size } \\
(\mu \mathrm{m})\end{array}$ & $\begin{array}{l}\text { Pore Size } \\
(\mu \mathrm{m})\end{array}$ & $\begin{array}{l}\text { Measured } \\
\text { Pore Size } \\
(\mu \mathrm{m})\end{array}$ & $(\%)$ & $\begin{array}{l}\text { Contact } \\
\text { Angle }\left(^{\circ}\right)\end{array}$ & (Water, bar) & (Water, bar) & Thickness $(\mu \mathrm{m})$ & $(\mu \mathrm{m})$ \\
\hline 0.1 & $\begin{array}{l}0.211 \\
( \pm 0.007)\end{array}$ & $\begin{array}{l}0.274 \\
( \pm 0.003)\end{array}$ & $\begin{array}{l}0.357 \\
( \pm 0.003)\end{array}$ & $\begin{array}{l}80.8 \\
( \pm 1.66)\end{array}$ & $143( \pm 1.4)$ & 5 & 6.9 & 49 & $53( \pm 3.9)$ \\
\hline 0.45 & $\begin{array}{l}0.653 \\
( \pm 0.004)\end{array}$ & $\begin{array}{l}0.87 \\
( \pm 0.02)\end{array}$ & $\begin{array}{l}1.2 \\
( \pm 0.03)\end{array}$ & $\begin{array}{l}83.9 \\
( \pm 0.82)\end{array}$ & $136( \pm 0.52)$ & 2.3 & 2.1 & 51 & $63.4( \pm 9.6)$ \\
\hline 1 & $\begin{array}{l}1.17 \\
( \pm 0.06)\end{array}$ & $\begin{array}{l}1.36 \\
( \pm 0.09)\end{array}$ & $\begin{array}{l}2.0 \\
( \pm 0.2)\end{array}$ & $85.9( \pm 1.3)$ & $140( \pm 1.2)$ & 0.66 & 0.84 & 99 & $82.6( \pm 2.5)$ \\
\hline 3 & $\begin{array}{l}3.07 \\
( \pm 0.04)\end{array}$ & $\begin{array}{l}3.19 \\
( \pm 0.05)\end{array}$ & $\begin{array}{l}4.094 \\
( \pm 0.009)\end{array}$ & $87.3( \pm 1.9)$ & $135( \pm 1.0)$ & 0.58 & 0.49 & 77 & $77.5( \pm 2.1)$ \\
\hline 5 & $\begin{array}{l}5.2 \\
( \pm 0.3)\end{array}$ & $\begin{array}{l}5.43 \\
( \pm 0.12)\end{array}$ & $\begin{array}{l}7.19 \\
( \pm 0.07)\end{array}$ & $\begin{array}{l}88.2 \\
( \pm 0.65)\end{array}$ & $141( \pm 1.5)$ & 0.34 & 0.26 & 47 & $39( \pm 5.4)$ \\
\hline
\end{tabular}

${ }^{*}$ Porosity and liquid entry pressure measured according to the methods described by Smolders \& Franken (1989) and Rácz et al. (2014) respectively. 
Appendix B. Transition in feed $\mathrm{pH}$ during membrane distillation
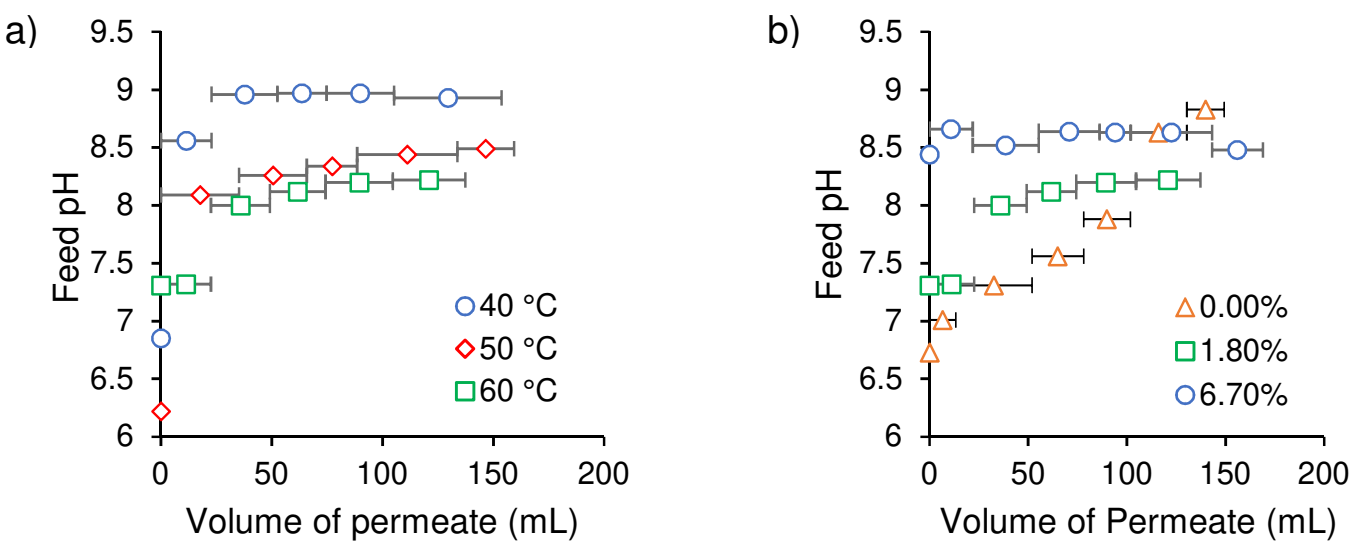

Figure B-1. Transient in pH identified in Feedwater during membrane distillation trials: (a) Blackwater comprising $1.8 \%$ wt. faecal contamination and feed water temperature varied between 40 and $60^{\circ} \mathrm{C}$; (b) Blackwater temperature fixed $\left(60^{\circ} \mathrm{C}\right.$ ) and faecal concentration varied between 0 and $6.7 \%$ wt (overlapping runs removed for figure clarity). Horizontal error bars indicate time periods permeate samples were collected over.

\section{Appendix C. Impact of temperature and retention time on blackwater feed}


Figure C-1. Impact of retention time on feed water characteristics at various feed temperatures. Feed: concentrated blackwater comprising 1.8\% faecal matter; mixing rate: $150 \mathrm{rpm}$. (a) Normalised total 
ammoniacal nitrogen concentration $\left[\left(\mathrm{NH}_{4}-\mathrm{N}\right)_{\text {final }} /\left(\mathrm{NH}_{4}-\mathrm{N}\right)_{\text {Initial]; }}\right.$ (b) normalised total ammonia [ $\left(\mathrm{NH}_{3}\right)_{\text {final }}$ $/\left(\mathrm{NH}_{3}\right)_{\text {initiall; }}$ (c) E. Coli (limit of detection, 1 log $10 \mathrm{cfu} \mathrm{mL}^{-1}$; (d) Dependency of E. Coli number on free ammonia concentration. Horizontal error bars indicate time periods permeate samples were collected over.

\section{Appendix D. Impact of faecal concentration and retention time on blackwater feed}
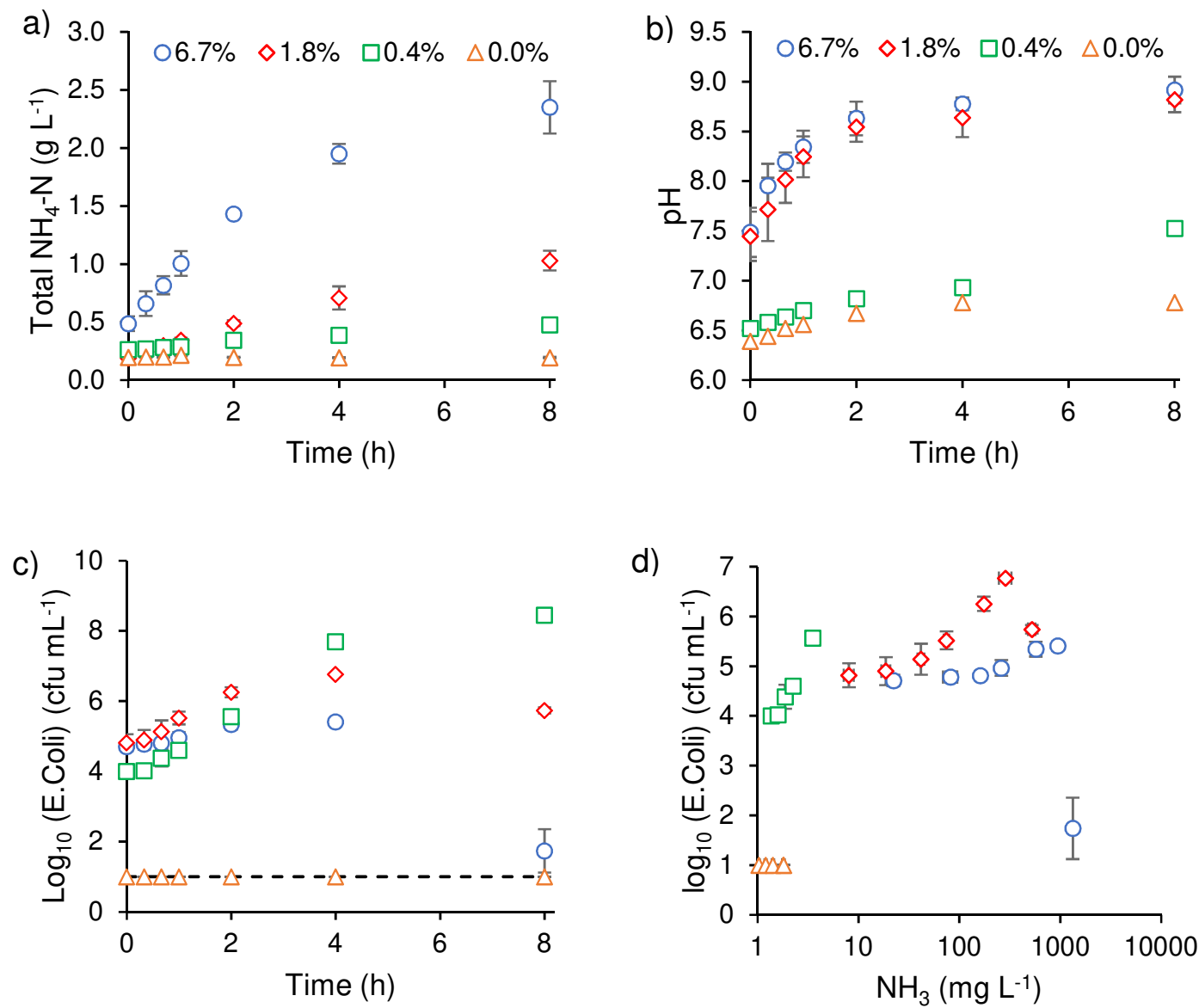

Figure D-1. Impact of retention time on feed water characteristics for various concentrations of faecal matter $\left(0,0.4,1.8\right.$, and 6.7 wt. \%). Feed temperature, $40{ }^{\circ} \mathrm{C}$; Mixing rate, $150 \mathrm{rpm}$. (a) Total ammoniacal nitrogen; (b) $\mathrm{pH}$; (c) E. Coli (limit of detection: dotted line, $1 \log _{10} \mathrm{cfu} \mathrm{mL}^{-1}$; (d) Dependency of E. Coli number on free ammonia concentration). 